\title{
Benzothiadiazole Conditions the Bean Proteome for Immunity to Bean Rust
}

\author{
Bret Cooper, ${ }^{1,+}$ Hunter S. Beard, ${ }^{1}$ Wesley M. Garrett, ${ }^{2}$ and Kimberly B. Campbell ${ }^{1}$ \\ ${ }^{1}$ Soybean Genomics and Improvement Laboratory, USDA-ARS, Beltsville, MD, U.S.A. \\ ${ }^{2}$ Animal Biosciences and Biotechnology Laboratory, USDA-ARS, Beltsville, MD, U.S.A.
}

Accepted 30 January 2020.

\begin{abstract}
The common bean rust fungus reduces harvests of the dry, edible common bean. Natural resistance genes in the plant can provide protection until a fungal strain that breaks resistance emerges. In this study, we demonstrate that benzo $(1,2,3)$ thiadiazole-7-carbothioic acid $S$-methyl ester (BTH) sprayed on susceptible beans induces resistance to common bean rust. Protection occurred as soon as $72 \mathrm{~h}$ after treatment and resulted in no signs of disease 10 days after inoculation with rust spores. By contrast, the susceptible control plants sustained heavy infections and died. To understand the effect BTH has on the bean proteome, we measured the changes of accumulation for 3,973 proteins using mass spectrometry. The set of 409 proteins with significantly increased accumulation in BTHtreated leaves included receptor-like kinases SOBIR1, CERK1, and LYK5, which perceive pathogens, and EDS1, a regulator of the salicylic acid defense pathway. Other proteins that likely contributed to resistance included pathogenesis-related proteins, a full complement of enzymes that catalyze phenylpropanoid biosynthesis, and protein receptors, transporters, and enzymes that modulate other defense responses controlled by jasmonic acid, ethylene, brassinosteroid, abscisic acid, and auxin. Increases in the accumulation of proteins required for vesicle-mediated protein secretion and RNA splicing occurred as well. By contrast, more than half of the 168 decreases belonged to chloroplast proteins and proteins involved in cell expansion. These results reveal a set of proteins needed for rust resistance and reaffirm the utility of BTH to control disease by amplifying the natural immune system of the bean plant.
\end{abstract}

Keywords: bean rust, BTH, mass spectrometry, Phaseolus vulgaris, proteomics, systemic acquired resistance, Uromyces appendiculatus

Bean rust fungi, namely the Uromyces spp., infect many varieties of commercially grown beans, causing farmers problems wherever rust appears. Bean rust disease is naturally

${ }^{\dagger}$ Corresponding author: B. Cooper; bret.cooper@ars.usda.gov

Funding: This project was funded by the United States Department of Agriculture Agricultural Research Service.

*The $\boldsymbol{e}$-Xtra logo stands for "electronic extra" and indicates that two supplementary figures and two supplementary datasets are published online.

The author(s) declare no conflict of interest.

This article is in the public domain and not copyrightable. It may be freely reprinted with customary crediting of the source. The American Phytopathological Society, 2020. controlled by bean resistance $(\mathrm{R})$ proteins that confer hypersensitive immunity to specific fungal isolates. For example, the Ur-3 and Ur-4 R proteins of the common dry edible bean Phaseolus vulgaris provide protection to numerous common bean rust strains (Hurtado-Gonzales et al. 2017; Lee et al. 2009). But not all are resisted. If the R protein combinations in the beans disagree with the rust isolates in the field, entire crop loss can occur during an outbreak.

$\mathrm{R}$ proteins function as receptors to specifically recognize, directly or indirectly, pathogen effector proteins that serve to disable the plant immune system to promote pathogen infection (Cook et al. 2015). Other types of receptors also exist within the plant immune system to recognize other types of pathogen proteins, carbohydrates, and metabolites (Cook et al. 2015). These receptor and recognition systems overlap and converge through salicylic acid (SA) and other hormonal signaling pathways that sustain, amplify, and transmit an immune response (Tsuda et al. 2009). In Arabidopsis thaliana, proteins EDS1 and PAD4 regulate SA responses from R proteins (Cui et al. 2017). Consequently, SA binding to NPR1/NPR3/NPR4 influences the expression of hundreds of genes needed for resistance (Ding et al. 2018). The expression output leads to protein and enzyme accumulation of the canonical pathogenesisrelated (PR) proteins, the chitinases, glucanases, inhibitors, proteases, peroxidases, and defensins that target a broad spectrum of pathogens (van Loon et al. 2006). The SA signal output also leads to the synthesis of phytoalexins (toxins) (Nawrath and Métraux 1999) and the alteration of cell-wall composition including callose deposition and lignification (Tateda et al. 2014), all of which contribute to resistance to pathogens including bean rust and soybean rust fungi (Cooper et al. 2013; Lee et al. 2009).

Besides being involved with defense signaling at the site of infection, SA and its intracellular mobile form, methyl-SA, contribute to systemic acquired resistance (SAR), whereby infection at one leaf leads to increased SA accumulation and enhanced disease resistance at another leaf (Gaffney et al. 1993). SAR can be induced by topical application of SA, and this serves as a means of disease protection by preconditioning a plant to resist infection from a broader spectrum of pathogens than conferred by any single R protein (Klessig et al. 2018). Besides SA, there are other endogenous plant molecules that also transmit signals to induce SAR, including pipecolic acid through a mechanism that is both SA-dependent and SAindependent (Bernsdorff et al. 2016; Chen et al. 2018; Hartmann et al. 2018). Other SAR inducers include dicarboxylic acid azelaic acid, abietane diterpenoid dehydroabietinal, and a glycerol-3-phosphate-dependent factor (Dempsey and Klessig 2012; Shah et al. 2014). Synthetic compounds like benzo(1,2,3) thiadiazole-7-carbothioic acid $S$-methyl ester (BTH) also can induce SAR (Görlach et al. 1996; Lawton et al. 1996). A 
commercial product sold to protect plants from myriad diseases, BTH may induce SAR through NPR1 or through multiple, overlapping pathways that include NPR1 (Delaney et al. 1994; Kohler et al. 2002).

Historical studies revealed that protein accumulation is an initial consequence of SAR (van Loon et al. 2006). Technology from the era of the early studies limited the identification to a few sets of PR proteins. Much about SAR has been learned since then, and we now know that there are several hundred to a thousand transcriptional changes associated with SAR (Blanco et al. 2009; Ding et al. 2018; Glazebrook et al. 2003; Krinke et al. 2007; Wang et al. 2005). Such a detailed proteomic picture, however, has not kept pace with the transcriptional landscape. So we aimed to use modern, high-throughput, quantitative mass spectrometry to measure protein accumulation changes associated with SAR. In this study, we examined the efficacy of $\mathrm{BTH}$ for inducing resistance to bean rust. We then evaluated the bean immune system after BTH application. Our examination of 3,973 proteins is the largest quantitative proteomic analysis, to date, for any plant undergoing SAR (Dong et al. 2016; Wu et al. 2015). The results describe a network of proteins that intersect SA defense pathways but also other hormonal pathways that appear to be involved in rust resistance.

\section{RESULTS}

\section{Protection by BTH.}

Previously, it was demonstrated that BTH application 7 days prior to rust challenge was better at protecting beans from common bean rust infection than the shorter waiting period of 3 days (Iriti and Faoro 2003). Knowing the need to protect plants as early as possible, we re-evaluated shorter waiting periods. In our preliminary tests, we observed no protection to rust when waiting 24 or $48 \mathrm{~h}$ after BTH application, but there was equivalent protection after waiting 72,96 , and $120 \mathrm{~h}$ when applying $0.7 \mathrm{mM}$ BTH. We subsequently evaluated the 72-h waiting period in more detail. In three replicate trials, we found that BTH-treated leaves had no discernable pustules at 10 days postinoculation, whereas the water-treated controls were severely infected (Fig. 1A and B). In some cases, we observed only 1 or 2 pustules on BTH-treated leaves at 15 days postinoculation, but, by this time, the infected water-treated leaves died and abscised.

In contrast to BTH, 4.8-mM SA application and a 72-h waiting period reduced pustules only by $39 \%$ (Fig. 1C). Just as we observed for BTH, SA conferred no protection in preliminary trials with 24 - and 48 -h waiting periods, and the weaker SA protection observed at $72 \mathrm{~h}$ weakened further after waiting $96 \mathrm{~h}$. We were not able to assess whether protection increased with greater concentrations of SA because the greater concentrations caused leaf burn (phytotoxicity). SA phytotoxicity from concentrations greater than $5 \mathrm{mM}$ have been previously reported (Sillero et al. 2012). Depending on the plant, lower concentrations of SA also can be phytotoxic and not provide greater protection than what we observed (Kliebenstein et al. 2006; Sillero et al. 2012). Thus, BTH is preferable to SA because, even under heavy inoculum load, it induced near complete resistance in beans as soon as 3 days after application.

\section{Quantitative mass spectrometry of BTH-treated bean leaves.}

Wanting to know how BTH induces immunity in bean leaves, we used quantitative mass spectrometry to evaluate protein accumulation changes in control and BTH-treated leaves prior to rust inoculation. Proteins were isolated from leaves and were digested with trypsin. The peptides from each sample (three replicates of BTH-treated and three replicates of water-treated, six samples total) were chemically labeled with a unique, isobaric tandem mass tag (TMT) (Isasa et al. 2015). The labeled peptide samples were combined and analyzed by mass spectrometry. Phosphopeptides were enriched from an aliquot of combined peptides and were analyzed as well. Overall, we identified 28,909 bean peptides, including 447 phosphopeptides. Parsimony, filtering, and grouping assigned those peptides to 3,973 quantified bean proteins (Supplementary Dataset $\mathrm{S} 1)$. The normalized and scaled sum of the peptide TMT reporter ion signal-to-noise $(\mathrm{S} / \mathrm{N})$ ratios per protein were used for quantitation. The $\log _{2}$ fold changes of all proteins exhibited a normal distribution (Fig. 2A). Spearman ranked correlation clustering of the quantitative values revealed that the BTH-treated samples clustered together, pointing to the reproducibility of the experiments (Fig. 2B). Statistical analysis
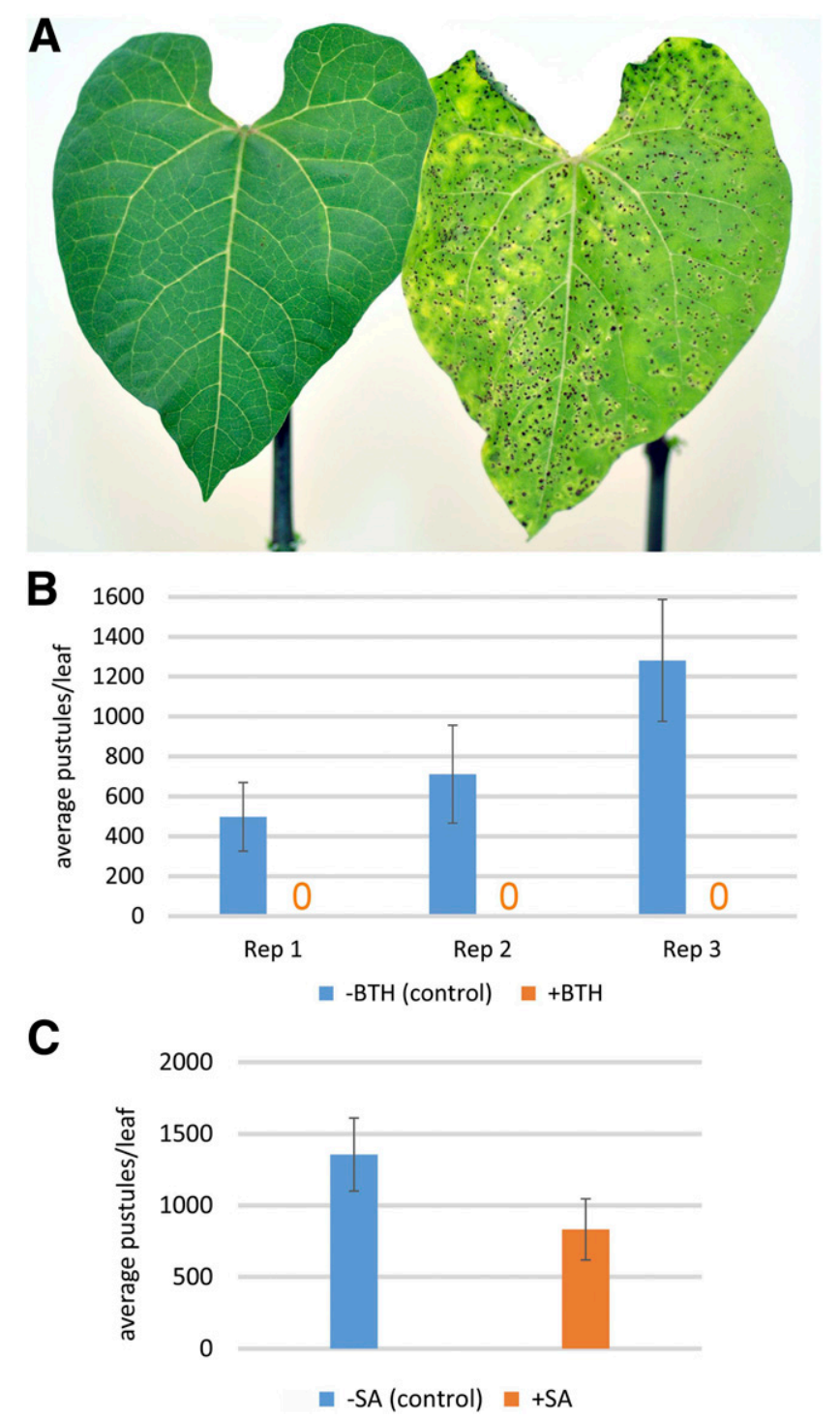

Fig. 1. Rust disease on benzo(1,2,3)thiadiazole-7-carbothioic acid $S$-methyl ester (BTH)-treated and water-treated bean leaves. A, Phaseolus vulgaris variety Black Valentine was sprayed with $0.7 \mathrm{mM} \mathrm{BTH}$ and was inoculated with bean rust $72 \mathrm{~h}$ later (left) or was water-sprayed and inoculated (right). The photo was taken 10 days after inoculation. B, Average number of pustules per primary leaf $(n=14)$ for BTH-treated and water-treated plants at 10 days after inoculation. BTH-treated plants had zero visible pustules. C, Average number of pustules per primary leaf $(n=20)$ for $4.8 \mathrm{mM}$ salicylic acid (SA)-treated and water-treated plants at 10 days after inoculation. There was a $72-\mathrm{h}$ period between BTH or SA application and inoculation. 
A

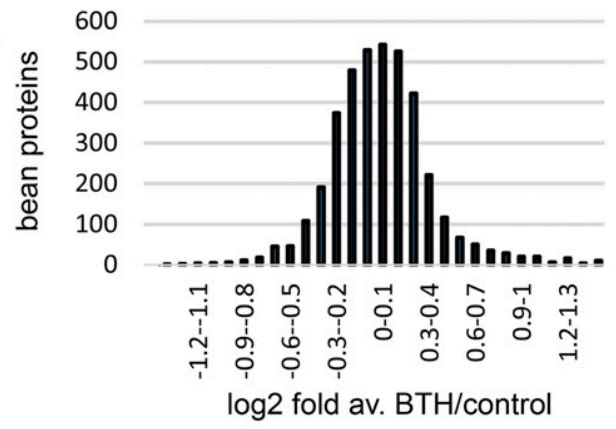

B

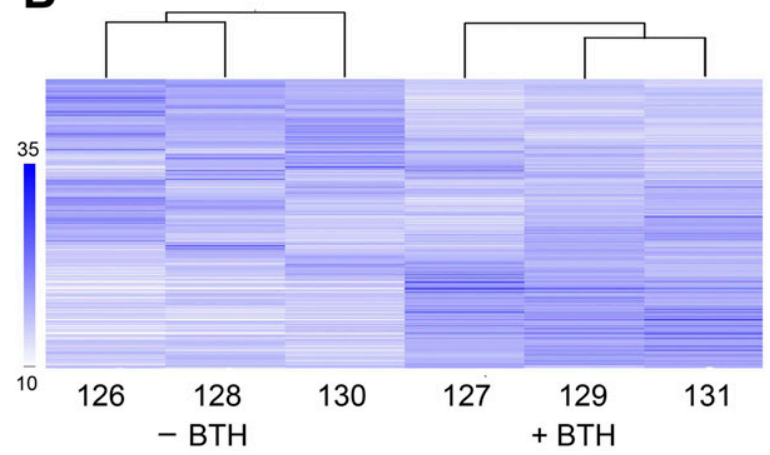

C

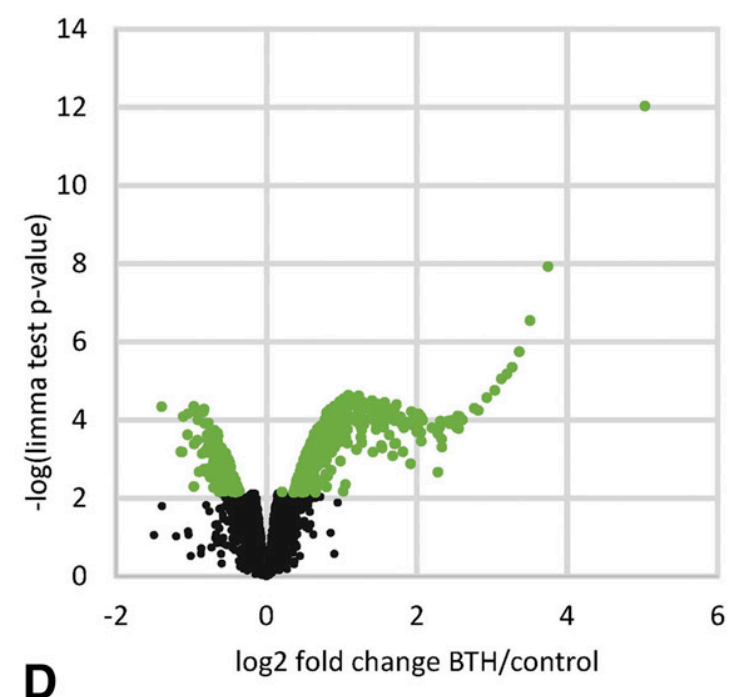

D



identified 577 proteins with significant accumulation changes arising from BTH treatment greater than or less than $0.35\left(\log _{2}\right)$ with a false discovery rate (FDR) $<5 \%$ (Fig. 2C). Among these, there were 409 proteins with increased accumulation in BTHtreated leaves and 168 proteins with decreased accumulation. Of those, there were 31 phosphoproteins with increased accumulation (Table 1) and 14 phosphoproteins with decreased accumulation.

By categorizing proteins on their predicted subcellular localization, we found that the set of 409 proteins with increased accumulation had, in terms of percent distribution, twice the amount assigned to the cytoplasm and extracellular domain, and four to five times the amount localized to the endoplasmic reticulum (ER), nucleus, and peroxisome (Fig. 2D). This implied that the set of proteins that increased in accumulation was different than the set that decreased.

\section{BTH increases receptor-kinase accumulation and affects multiple hormonal pathways.}

In BTH-treated bean leaves, there were at least 120 proteins with increased accumulation with corresponding A. thaliana orthologs described in published literature as having direct and associated roles in immunity, disease resistance, and stress response. These proteins included numerous canonical PR proteins known to be induced by SA. Furthermore, in the set, there were two orthologs of EDS1, an ortholog of EDS1-interacting SAG101 (Feys et al. 2005), and two proteins orthologous to NDR1, which is required for SAR (Shapiro and Zhang 2001) (Table 2). Also found increased were SA-binding protein SABP2 (Kumar and Klessig 2003), DMR6 (Zhang et al. 2017b), and OM66, which regulate SA homeostasis and signaling (Zhang et al. 2014a). One of the proteins with one of the greatest accumulation changes was a carboxylesterase that belongs to the same hormone-sensitive lipase family as SABP2 (Kumar and Klessig 2003). These results indicate that BTH affected SA-regulated pathways.

Also among the increased proteins were those potentially associated with $\mathrm{R}$ protein immunity. One, an ortholog of SGT1B, had increased phosphorylation (Azevedo et al. 2002) (Table 1). Others appeared to be receptor-like kinases that likely function upstream of EDS1. These included an ortholog of SOBIR1, which activates a defense pathway suppressed by BIR1, a negative regulator of BAK1 (the brassinosteroid [BR] kinase that homodimerizes with the flagellin receptor FLS2) (Albert et al. 2015; Zhang et al. 2013). We also found orthologs of receptor-like kinase CERK1 critical for chitin elicitor signaling (Miya et al. 2007), its receptor-like kinase interactor LYK5 (Erwig et al. 2017), and two CIPP1 (CERK-interacting)

$$
<
$$

Fig. 2. Bean proteins quantified after treatment with benzo(1,2,3)thiadiazole-7-carbothioic acid $S$-methyl ester (BTH). A, Distribution of $\log _{2}$ average of normalized and scaled tandem mass tag (TMT) reporter ion $\mathrm{S} / \mathrm{N}$ values for proteins from BTH-treated beans divided by the same for proteins from water-treated (control) beans. Bins are increments of 0.1. B, Spearman ranked correlation hierarchical clustering of the normalized and scaled TMT reporter ion summed $\mathrm{S} / \mathrm{N}$ values for proteins from three biological replicates $(126=$ control R1, $127=\mathrm{BTH}$ R1, $128=$ control R2, $129=$ BTH R2, $130=$ control R3, 131 = BTH R3). The scale bar shows that blue is the highest amount of relative accumulation $(>35)$ and white is the lowest $(<10)$. Clustering was performed with Treeview 3.0. C, Volcano distribution of fold-changes between bean proteins from BTH-treated and water-treated (control) leaves as a function of $-\log$ (limma test $P$ value) for each set of reporter ion $\mathrm{S} / \mathrm{N}$ values for each protein. Significantly different bean proteins $(n=409)$ with $P$ values with $\leq 5 \%$ false discovery rate (FDR) are in green and those with $>5 \%$ FDR are in black. D, Distribution of predicted cellular localizations for 409 proteins with increased accumulation in BTH-treated leaves and for 168 proteins with decreased accumulation in BTH-treated leaves. 
protein phosphatases that balance immune signaling output from the receptors (Liu et al. 2018) (Tables 1 and 2). Altogether, we found 17 increased receptor-like kinases. It is possible that some of these are responsible for sustained phosphorylation for the 31 phosphoproteins that increased in accumulation, including a PEN3 ABC transporter ortholog (Table 1). In A. thaliana, PEN3 is crucial for transporting glucosinolates to resist fungi that penetrate cells (Clay et al. 2009). Along this line, there were increased amounts of at least 20 enzymes in the phenylpropanoid pathway (Fig. 3) that produces phytoalexins and cell wall-fortifying lignin to prevent rust infection when R-protein immunity is activated or when pathogen elicitors are applied (Bolwell et al. 1985; Cooper et al. 2013; Lee et al. 2009; Robbins et al. 1985).

Two of the increased receptor-like kinases are an ortholog of IOS1, which attenuates abscisic acid (ABA) responses (Hok et al. 2014) and interacts with CERK1 (Yeh et al. 2016), and the other is an ortholog of FERONIA, which is important for immunity but also suppresses jasmonic acid (JA) signaling (Guo et al. 2018) (Table 2). These increases of proteins that function through ABA and JA hormonal pathways imply that BTH influences other hormonal responses in addition to SA. This appeared to be true with increased amounts of an ortholog of RAE1 that negatively regulates ABA by degrading the ABA receptor RCAR1 (Li et al. 2018) and BEN1 and TPR4, which positively increase levels of BR (Oh et al. 2014; Yuan et al. 2007) (Table 2). Meanwhile, the enzyme 1-aminocyclopropane carboxylate oxidase (ACO) that converts 1aminocyclopropane-1-carboxylic acid (ACC) into ethylene (ET) was increased, as was EIN2, the protein that regulates ET signaling during pathogen defense (Tintor et al. 2013) (Table 2).

\section{BTH alters cellular machinery.}

The prediction of cellular localization revealed a greater distribution of extracellular proteins with increased accumulation (Fig. 2D). Many of these extracellular proteins include PR proteins. Because of the increase in secreted proteins, we assumed that there might be a concomitant increase in ER and vesicle-mediated transport machinery needed for protein

Table 1. Phosphoproteins with significantly increased accumulation in benzo(1,2,3)thiadiazole-7-carbothioic acid $S$-methyl ester (BTH)-treated beans

\begin{tabular}{|c|c|c|c|c|c|c|c|}
\hline Protein & Annotation & $\begin{array}{c}\log _{2} \text { fold } \\
\text { change } \\
\text { BTH/control }\end{array}$ & $\begin{array}{c}\text { Predicted } \\
\text { cellular } \\
\text { localization }\end{array}$ & $\begin{array}{c}\text { Arabidopsis } \\
\text { thaliana } \\
\text { ortholog }\end{array}$ & Function & $\begin{array}{c}P \\
\text { value }\end{array}$ & Phospho site \\
\hline Phvul.001G040300.1.p & $\begin{array}{l}\text { L-type lectin-domain } \\
\text { receptor kinase }\end{array}$ & 1.6 & Cell membrane & AT5G10530 & Immunity & $4 \mathrm{E}-5$ & S366 \\
\hline Phvul.007G243200.1.p & $\begin{array}{l}\mathrm{ABC} \text { transporter } \mathrm{G} \\
\text { family member }\end{array}$ & 1.3 & Cell membrane & AT1G53390 & Membrane transport & $2 \mathrm{E}-4$ & S645 \\
\hline Phvul.008G212500.1.p & LYK5 & 1.2 & Cell membrane & AT2G33580 & Immunity & $9 \mathrm{E}-5$ & $\mathrm{~S} 134$ \\
\hline Phvul.010G024600.1.p & Ribosomal protein $\mathrm{S} 8$ & 1.1 & Cytoplasm & AT5G59240 & Ribosome & $2 \mathrm{E}-5$ & $\begin{array}{c}\text { S689; S690; S691; } \\
\text { S873; S2946; } \\
\text { S4457; S4457 }\end{array}$ \\
\hline Phvul.008G154713.1.p & Unknown & 1.1 & Golgi apparatus & No match & Unknown & $3 \mathrm{E}-4$ & S530 \\
\hline Phvul.L001947.1.p & $\begin{array}{l}\text { Inorganic phosphate } \\
\text { transporter }\end{array}$ & 0.99 & Cell membrane & AT3G54700 & Phosphate transport & $1 \mathrm{E}-3$ & $\mathrm{~S} 100$ \\
\hline Phvul.004G104600.1.p & SGT1B & 0.92 & Cytoplasm & AT4G11260 & Immunity & $5 \mathrm{E}-5$ & S98 \\
\hline Phvul.009G027000.1.p & Unknown & 0.92 & Nucleus & AT4G08550 & Unknown & $5 E-5$ & $\mathrm{~S} 224$ \\
\hline Phvul.001G172700.2.p & RS2Z32 & 0.88 & Nucleus & AT3G53500 & Splicing & $2 \mathrm{E}-4$ & S18 \\
\hline Phvul.004G170800.1.p & $\begin{array}{l}\text { NADP-dependent } \\
\text { malic enzyme }\end{array}$ & 0.80 & Peroxisome & AT1G79750 & Malate metabolism & $1 \mathrm{E}-4$ & S198 \\
\hline Phvul.007G116000.1.p & F-box protein $\mathrm{PP} 2-\mathrm{B} 10$ & 0.78 & Cytoplasm & AT2G02360 & Immunity & $1 \mathrm{E}-4$ & S13 \\
\hline Phvul.008G148700.1.p & $\begin{array}{l}\text { Glucose-6-phosphate } \\
\text { 1-dehydrogenase }\end{array}$ & 0.74 & Cytoplasm & AT5G40760 & Immunity & $2 \mathrm{E}-4$ & $\mathrm{~S} 285 ; \mathrm{S} 289$ \\
\hline Phvul.007G066560.1.p & RS40 & 0.63 & Nucleus & AT4G25500 & Splicing & $3 \mathrm{E}-4$ & S833; S850; S861 \\
\hline Phvul.010G145600.1.p & PEN3 & 0.61 & Cell membrane & AT1G59870 & Immunity & $3 \mathrm{E}-3$ & S8 \\
\hline Phvul.006G087600.1.p & Glutamate decarboxylase & 0.58 & Cytoplasm & AT5G17330 & $\begin{array}{l}\text { Glutamate } \\
\text { metabolism }\end{array}$ & $2 \mathrm{E}-3$ & $\mathrm{~S} 10$ \\
\hline $\begin{array}{l}\text { Phvul.004G082700.1.p } \\
\text { Phvul.004G082894.1.p }\end{array}$ & PIP2;2 & 0.55 & Cell membrane & AT2G37170 & Water transport & $5 \mathrm{E}-3$ & S405 \\
\hline Phvul.008G155500.1.p & $\mathrm{S} / \mathrm{T}$ protein kinase & 0.53 & Nucleus & AT5G40340 & Flowering & $8 \mathrm{E}-4$ & S115 \\
\hline Phvul.006G206300.1.p & CIPP1 & 0.52 & Plastid & AT1G34750 & Immunity & $2 \mathrm{E}-3$ & $\mathrm{~S} 85$ \\
\hline Phvul.003G294800.3.p & RBP47 & 0.51 & Nucleus & AT3G19130 & RNA processing & $2 \mathrm{E}-3$ & $\mathrm{~S} 252$ \\
\hline Phvul.011G026600.1.p & $\begin{array}{l}\text { Translocon-associated } \\
\text { protein }\end{array}$ & 0.50 & Cell membrane & AT2G16595 & $\begin{array}{l}\text { Protein processing } \\
\text { in the } \\
\text { endoplasmic } \\
\text { reticulum (ER) }\end{array}$ & $1 \mathrm{E}-3$ & S308 \\
\hline Phvul.001G186200.1.p & U2AF35B & 0.46 & Nucleus & AT5G42820 & Splicing & $2 \mathrm{E}-3$ & S120; S121 \\
\hline Phvul.001G098000.1.p & WD repeat & 0.45 & Nucleus & AT1G12910 & $\begin{array}{r}\text { Anthocyanin } \\
\text { production }\end{array}$ & $7 E-3$ & S110; S200; S205 \\
\hline Phvul.007G270200.1.p & RSZ32 & 0.44 & Nucleus & AT3G53500 & Splicing & $2 \mathrm{E}-3$ & S807 \\
\hline Phvul.001G077100.1.p & ABC family protein & 0.44 & ER & AT5G24810 & Unknown & $4 \mathrm{E}-3$ & S960; S963 \\
\hline Phvul.001G029800.1.p & PRP40A & 0.44 & Nucleus & AT1G44910 & RNA processing & $5 E-3$ & S133; S139 \\
\hline Phvul.010G072400.1.p & $\begin{array}{l}\text { Vesicle-associated } \\
\text { protein } 1-2\end{array}$ & 0.42 & ER & AT2G45140 & $\begin{array}{l}\text { Vesicle mediated } \\
\text { transport }\end{array}$ & $6 \mathrm{E}-3$ & S173 \\
\hline Phvul.006G029300.1.p & CWC22 & 0.41 & Nucleus & AT1G80930 & Splicing & $4 \mathrm{E}-3$ & $\mathrm{~S} 452$ \\
\hline Phvul.005G181500.1.p & $\mathrm{BRAP} 2$ ring $\mathrm{Zn}$ finger & 0.40 & Cytoplasm & AT2G26000 & Unknown & $6 \mathrm{E}-3$ & T529 \\
\hline Phvul.003G098200.1.p & $\begin{array}{l}\text { Pyruvate phosphate } \\
\text { dikinase }\end{array}$ & 0.40 & Mitochondrion & AT4G15530 & $\begin{array}{l}\text { Pyruvate } \\
\text { metabolism }\end{array}$ & $6 \mathrm{E}-3$ & S4; S6; S8; T9 \\
\hline Phvul.003G219400.1.p & Lactate dehydrogenase & 0.37 & Cytoplasm & AT4G17260 & Glycolysis & $7 E-3$ & $\mathrm{~S} 795$ \\
\hline $\begin{array}{l}\text { Phvul.007G149432.1.p } \\
\text { Phvul.007G149366.1.p }\end{array}$ & Cell division cycle 48 & 0.37 & Cytoplasm & AT5G03340 & $\begin{array}{l}\text { Protein processing } \\
\text { in the ER }\end{array}$ & $7 \mathrm{E}-3$ & S317 \\
\hline
\end{tabular}


secretion. Indeed, there were 49 proteins with increased accumulation predicted to localize to the ER, whereas only four ER proteins decreased. These proteins include protein disulfide isomerases, glycosyltransferases, cytochrome $\mathrm{P} 450$ reductases, calreticulins, calnexins, heat-shock proteins, luminal-binding proteins, translocon SEC63, vesicle-associated proteins, and signal peptidases (Supplementary Fig. S1).

There also was a preponderance of nuclear proteins with increased accumulation (Fig. 2D). Among the nuclear proteins were at least 13 proteins attributed to pre-mRNA processing and transcript splicing, including orthologs of SCL30, SRZ22, CWC22, PRP40A, U2AF35B, RS40, RBP47, and RSZ32. The CWC22, PRP40A, U2AF35B, RS40, RBP47, and RSZ32 orthologs had increased amounts of phosphorylation as well (Table 1). Splicing regulation is controlled by phosphorylation and is known to influence immune response (Zhang et al. 2014b, 2017a).

\section{Bean proteins with decreased accumulation include plastid proteins.}

Of all 168 proteins with decreased accumulation arising from BTH application, half had predicted localization to the chloroplast (Fig. 2D). This included at least eight enzymes catalyzing the synthesis of chlorophyll and many other structural chloroplast proteins that compose the photosystems and thylakoid membranes (Supplementary Fig. S2).

Besides this effect on plastid proteins, there were reduced amounts of proteins that appear to function in cell-wall organization and expansion. Six of the top 10 proteins with the greatest reductions in accumulation are predicted to function at the cell wall or cuticle. There were at least 12 other proteins with functions that could be attributed to cell-wall organization. Furthermore, two proteins with some of the greatest reductions were orthologous to auxin-regulated FLA2 and patellin (Table 2). In A. thaliana, FLA2 associates with auxin exporter PIN1 (Titapiwatanakun et al. 2009) and A. thaliana patellin mutants have defects in cell development (Tejos et al. 2018). Furthermore, two homologs of ABCB1, another auxin exporter
(Noh et al. 2001), were reduced. These findings imply that auxin signaling was repressed, possibly to reduce cell expansion to promote lignification. Meanwhile, there were decreased amounts of an ortholog of CIPK3, which controls ABA responses to stress, including dehydration (Kim et al. 2003) (Table 2). Coinciding with this, there were decreased amounts of orthologs to ABA-regulated aquaporin PIP2;7 and PIP2;2 that are important for cell membrane water permeability during salinity stress (Boursiac et al. 2005; Jang et al. 2004; Pou et al. 2016).

\section{Comparison with published gene expression and proteomics data.}

Over the last 20 years, many laboratories have measured gene expression changes in A. thaliana treated with SA. By using BLAST to match $A$. thaliana genes to bean proteins, we compared some of the A. thaliana gene-expression data to the bean protein changes reported here. Using Affymetrix GeneChips representing 8,200 genes, Wang et al. (2005) measured 197 gene expression changes between NPRl transgenic and nprl mutant plants treated with SA for $24 \mathrm{~h}$. Those authors hypothesized that the comparative analysis would refine the set of SAR responses controlled through NPR1. Of these gene expression changes, 20 correlated with the protein changes observed in BTH-treated beans. The overlap included EDS1 and LYK5 and proteins involved in protein processing at the ER. Using a different array of 24,576 A. thaliana gene-specific tags, Krinke et al. (2007) measured 792 gene expression changes in A. thaliana cell suspensions treated with SA for $4 \mathrm{~h}$. There were 54 gene-expression changes that shared the same direction of change as the bean proteins. Among these proteins were DMR6, EDS1, PR4, PEN3, and FLA2. Blanco et al. (2009) used a cDNA array to measure changes in 18,981 genes between $A$. thaliana wild type and $n p r l$ mutants treated with SA for $2.5 \mathrm{~h}$. They identified 217 expression changes, but only 18 overlapped with the bean protein changes, including CERK1, IOS1, and DMR6. More recently, Ding et al. (2018) used high-throughput cDNA sequencing to find 2,455 differentially expressed genes between A. thaliana wild type and

Table 2. Proteins with significantly altered accumulation in benzo(1,2,3)thiadiazole-7-carbothioic acid $S$-methyl ester (BTH)-treated beans

\begin{tabular}{|c|c|c|c|c|c|c|}
\hline Protein & Annotation & $\begin{array}{c}\log _{2} \text { fold change } \\
\text { BTH/control }\end{array}$ & $\begin{array}{l}\text { Predicted cellular } \\
\text { localization }\end{array}$ & $\begin{array}{c}\text { Arabidopsis thaliana } \\
\text { ortholog }\end{array}$ & Function $^{\mathbf{a}}$ & $P$ value \\
\hline Phvul.009G183000.1.p & EDS1 & 0.66 & Mitochondrion & AT3G48080 & Immunity/SA signaling & $8 \mathrm{E}-4$ \\
\hline Phvul.009G183100.1.p & EDS1 & 1.7 & Peroxisome & AT3G48090 & Immunity/SA signaling & $7 \mathrm{E}-5$ \\
\hline Phvul.004G020000.1.p & SAG101 & 1.5 & Cytoplasm & AT5G14930 & Immunity/SA signaling & $6 \mathrm{E}-5$ \\
\hline Phvul.001G194700.1.p & NDR1 & 1.7 & Cell membrane & AT2G35980 & Immunity/SA signaling & $4 \mathrm{E}-4$ \\
\hline Phvul.001G194600.1.p & NDR1 & 1.8 & Cell membrane & AT2G35980 & Immunity/SA signaling & $7 \mathrm{E}-4$ \\
\hline Phvul.003G248075.1.p & SABP2 & 0.79 & Cytoplasm & AT2G23620 & SA homeostasis & $1 \mathrm{E}-3$ \\
\hline Phvul.009G044600.2.p & DMR6 & 2.3 & Cytoplasm & AT5G24530 & SA homeostasis & $2 \mathrm{E}-4$ \\
\hline Phvul.003G256600.1.p & OM66 & 0.74 & Cytoplasm & AT3G50930 & SA homeostasis & $2 \mathrm{E}-4$ \\
\hline Phvul.003G295200.1.p & Carboxylesterase & 3.3 & Cytoplasm & AT3G48700 & Hormone-sensitive lipase & $4 \mathrm{E}-6$ \\
\hline Phvul.009G171200.1.p & SOBIR1 & 1.3 & Cell membrane & AT2G31880 & Immunity & $5 \mathrm{E}-5$ \\
\hline Phvul.006G006700.1.p & CERK1 & 0.53 & Cell membrane & AT3G21630 & Immunity & $1 \mathrm{E}-3$ \\
\hline Phvul.002G209700.1.p & CIPP1 & 0.54 & Plastid & AT1G34750 & Immunity & $2 \mathrm{E}-3$ \\
\hline Phvul.005G164500.1.p & IOS1 & 2.1 & Cell membrane & AT1G51800 & Immunity/ABA signaling & $8 \mathrm{E}-5$ \\
\hline Phvul.008G030800.1.p & FERONIA & 0.97 & Cell membrane & AT3G51550 & Immunity/JA signaling & $4 \mathrm{E}-4$ \\
\hline Phvul.003G032400.1.p & RAE1 & 0.43 & Nucleus & AT1G80670 & ABA signaling & $3 \mathrm{E}-3$ \\
\hline Phvul.008G076600.1.p & BEN1 & 2.0 & Cytoplasm & AT2G45400 & $\mathrm{BR}$ regulation & $1 \mathrm{E}-4$ \\
\hline Phvul.003G167500.1.p & TPR4 & 0.38 & Cytoplasm & AT3G15880 & $\mathrm{BR}$ regulation & $6 \mathrm{E}-3$ \\
\hline Phvul.003G020200.2.p & $\mathrm{ACO}$ & 0.84 & Cytoplasm & AT1G03400 & ET biosynthesis & $4 \mathrm{E}-4$ \\
\hline Phvul.007G150600.1.p & EIN2 & 0.51 & Cell membrane & AT5G03280 & ET signaling & $7 \mathrm{E}-3$ \\
\hline Phvul.008G288800.1.p & FLA2 & -1.0 & Cell membrane & AT4G12730 & Auxin transport & $7 \mathrm{E}-5$ \\
\hline Phvul.009G157900.1.p & Patellin & -0.96 & Cytoplasm & AT1G72160 & Auxin-mediated cell elongation & $4 \mathrm{E}-4$ \\
\hline Phvul.001G179300.1.p & ABCB 1 & -0.69 & Cell membrane & AT2G36910 & Auxin regulation & $2 \mathrm{E}-4$ \\
\hline Phvul.007G147400.1.p & $\mathrm{ABCB} 1$ & -0.50 & Cell membrane & AT2G36910 & Auxin regulation & $6 \mathrm{E}-3$ \\
\hline Phvul.008G205700.1.p & CIPK3 & -0.52 & Cell membrane & AT2G26980 & $\mathrm{ABA}$ regulation & $9 \mathrm{E}-4$ \\
\hline Phvul.009G118900.1.p & PIP2;7 & -0.70 & Cell membrane & AT4G35100 & Water transport & $5 \mathrm{E}-3$ \\
\hline Phvul.004G082600.1.p & $\mathrm{PIP} 2 ; 2$ & -0.66 & Cell membrane & AT2G37170 & Water transport & $2 \mathrm{E}-3$ \\
\hline
\end{tabular}

\footnotetext{
${ }^{a} \mathrm{SA}=$ salicylic acid, $\mathrm{ABA}=$ abscisic acid, $\mathrm{JA}=$ jasmonic acid, $\mathrm{BR}=$ brassinosteroid, and $\mathrm{ET}=$ ethylene.
} 
nprl mutants treated with SA for $1 \mathrm{~h}$. Only 71 of those overlapped with the bean proteomics changes. The proteins included IOS1, DMR6, OM66, CIPP1, LYK5, NDR1, SOBIR1, SAG101, EDS1, CERK1, PEN3, CIPK3, and several proteins involved in ER protein processing and photosynthesis. From all four transcriptional studies, there were just two proteins, the CIPP1 protein phosphatase orthologs, that overlapped with our proteomics data. In $A$. thaliana, this phosphatase interacts with the chitin-elicitor receptor kinase CERK1 to regulate phosphorylation signaling output for disease resistance pathways (Liu et al. 2018). Altogether however, we found an overall lack of continuity between our proteomics data and published geneexpression data. We attribute this to imprecise matching between $P$. vulgaris and A. thaliana protein orthologs, possible differences between responses to BTH and SA application, differences between SAR in bean and A. thaliana, and a general lack of absolute congruence between gene-expression and protein-abundance data (Vogel and Marcotte 2012).

We also compared our data to 563 protein changes that we previously observed in beans genetically immune to rust infection (Lee et al. 2009). We found that the 51-protein overlap included not just PR proteins but also proteins involved in secretion and enzymes to produce phenylpropanoids. Furthermore, there was an overlap of proteins with reduced amounts of FLA2 and patellin, which together allude to an auxin response that may help promote lignification, and reduced amounts of PIP2;7, an ABA-regulated water transporter (Jang et al. 2004). There also was a corresponding reduction of chloroplast proteins. These results reveal that BTH alters the bean proteome similarly to a hypersensitive immune response to the bean rust fungus.
Evaluation of hormone and phenylpropanoid changes.

Our proteomics data reveal that BTH increased the accumulation of proteins in disease-resistance pathways that function through SA hormonal sectors. The proteomics data also implicate alterations in other hormonal pathways, such as those controlled or regulated by ET, ABA, and auxin. Furthermore, the increase in enzymes functioning in the phenylpropanoid pathway portends a possible increase in phenylpropanoids that lead to disease resistance. To test potential effects on hormone and phenylpropanoid production, we analyzed BTH-treated bean leaf extracts by mass spectrometry. The mass spectrometer was configured to specifically examine masses for SA, ACC, ABA, and auxin (indole-3-acetic acid). Phenylpropanoids trans-cinnamic acid, $p$-coumaric acid, trans-ferulic acid, and coumarin were evaluated as well (Fig. 3). Tandem mass spectrometry on the target masses produced diagnostic fragment ion masses for each molecule, and the abundance of these ions was compared with prednisone spiked into the samples. Overall, there were increased amounts of SA in BTH-treated plants (Fig. 4). Meanwhile, the amounts of ACC decreased (Fig. 4). Decreased amounts of ACC agree with increased amounts of ACO, which would deplete the ACC pool to form ET. As for ABA and auxin, there were no overall alterations in their abundance (Fig. 4). There also were no apparent alterations in the amounts of trans-cinnamic acid, p-coumaric acid, transferulic acid, and coumarin (Fig. 4).

\section{DISCUSSION}

Rust fungi, because of their wind dispersal and rapid adaptability, continue to cause problems in agriculture; not just

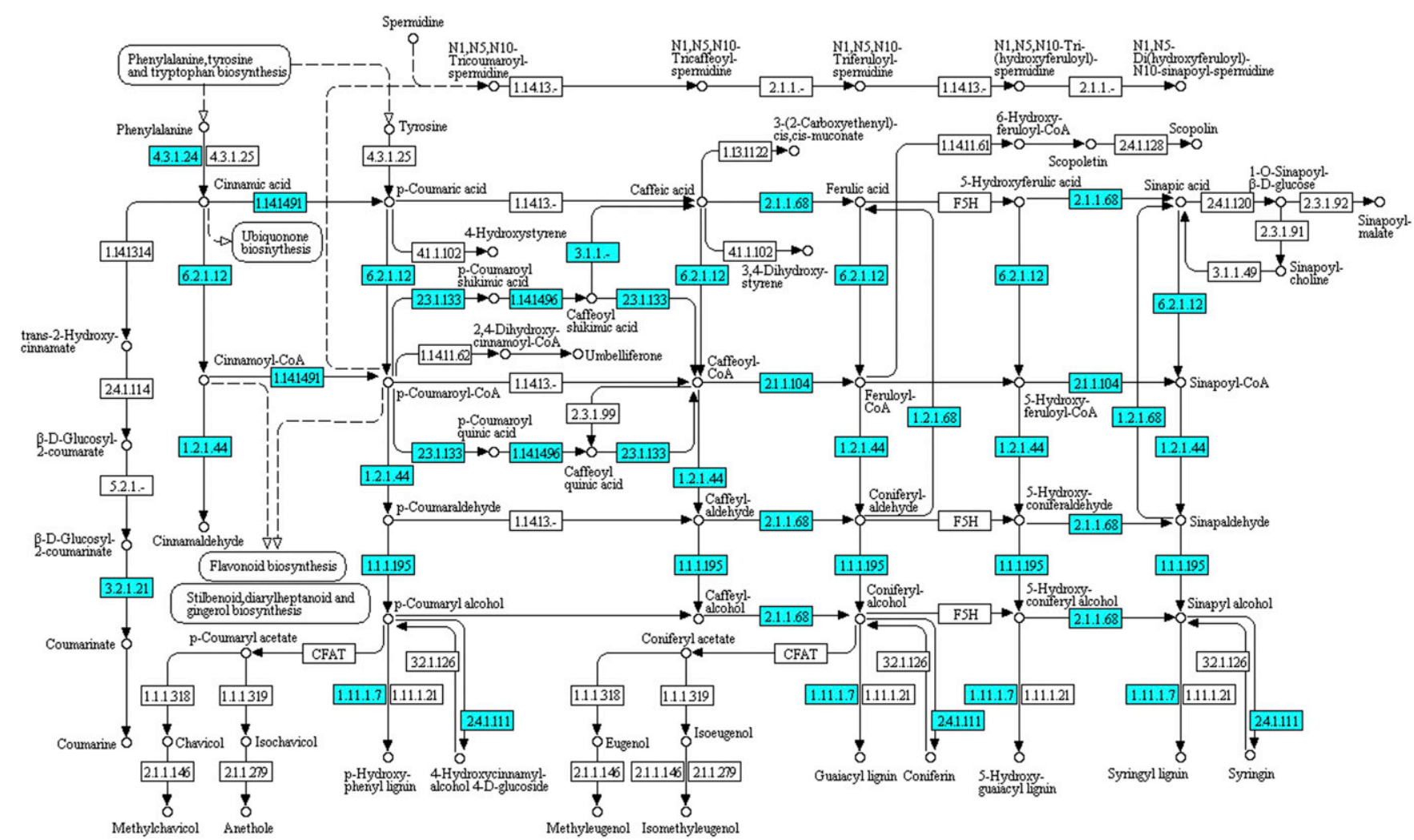

Fig. 3. A phenylpropanoid biosynthesis enzymatic pathway for Phaseolus vulgaris. Enzymes with increased accumulation from benzo(1,2,3)thiadiazole-7carbothioic acid $S$-methyl ester $(\mathrm{BTH})$ treatment are in blue. The pathway was produced by Kyoto Encyclopedia of Genes and Genomes: [EC 4.3.1.24]= Phvul.001G177700, Phvul.008G289500; [EC 1.14.14.91]=Phvul.008G247400; [EC 6.2.1.12]=Phvul.011G084300, Phvul.003G147000; [EC 2.3.1.133]= Phvul.010G162700; [EC 1.14.14.96]=Phvul.001G117900; [EC 3.1.1.-]=Phvul.003G140500; [EC 2.1.1.104] $=$ Phvul.003G047900, Phvul.004G172600; [EC 1.2.1.44]=Phvul.005G182100; [EC 1.2.1.68]=Phvul.002G314000; [EC 1.1.1.195]=Phvul.007G039800; [EC 2.1.1.68]=Phvul.009G258700; [EC 1.11.1.7]= Phvul.007G107400, Phvul.006G075900, Phvul.007G082700, Phvul.008G086800; [EC 2.4.1.111]=Phvul.002G096500; [EC 3.2.1.21]=Phvul.007G250300. 
to beans, but to soybeans, wheat, sugarcane, and other crops. The natural immune systems for these plants are strong and, with the aid of $\mathrm{R}$ proteins, can activate series of proteins, enzymes, and biochemicals that can thwart rust infection-at least until the rust fungus adapts to overcome the R-protein defense mechanism and renders that plant susceptible to disease. We show here, however, that topical application of BTH can precondition a susceptible bean plant to be immune to rust (Fig. $1 \mathrm{~A}$ and $\mathrm{B}$ ).

BTH application has a drastic effect on the leaf proteome. One observation is that BTH appears to activate many of the same SA defense pathways that are activated by R proteins. For

\section{SA}

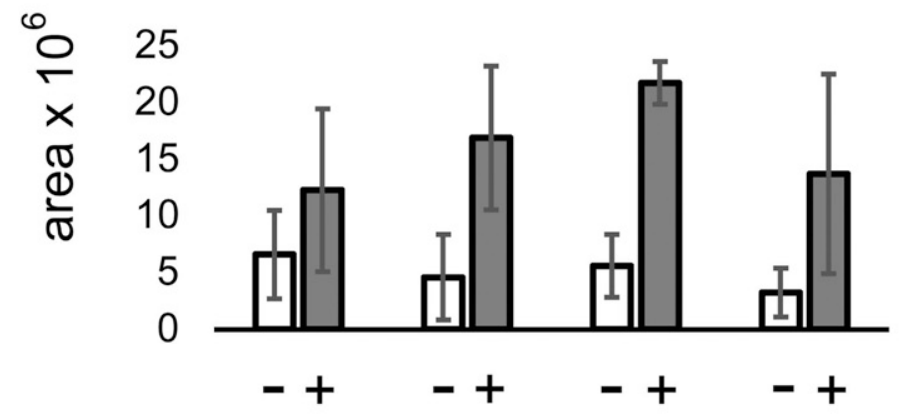

ACC

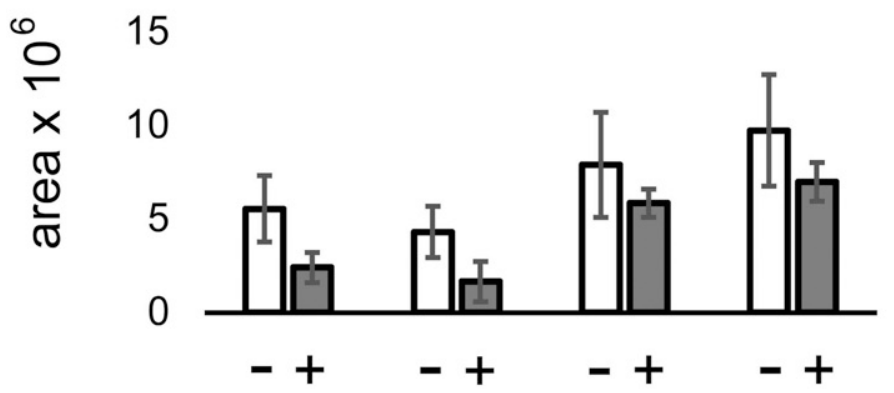

ABA

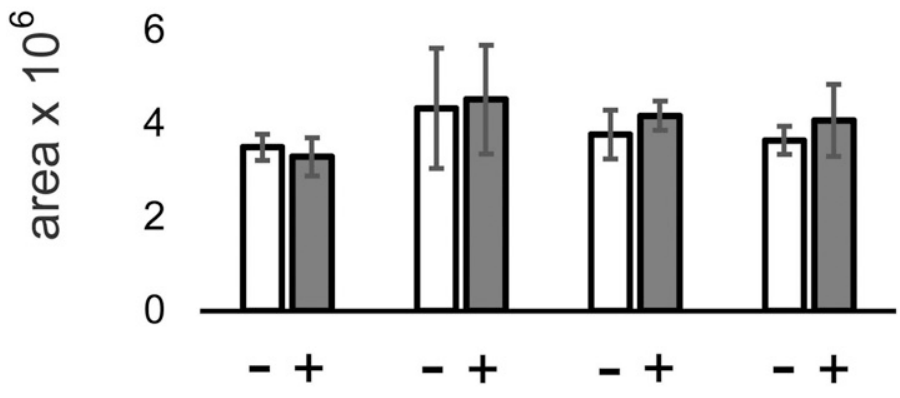

auxin

0
$\times$
$\frac{0}{\pi}$
$\frac{1}{\pi}$ trans-cinnamic acid

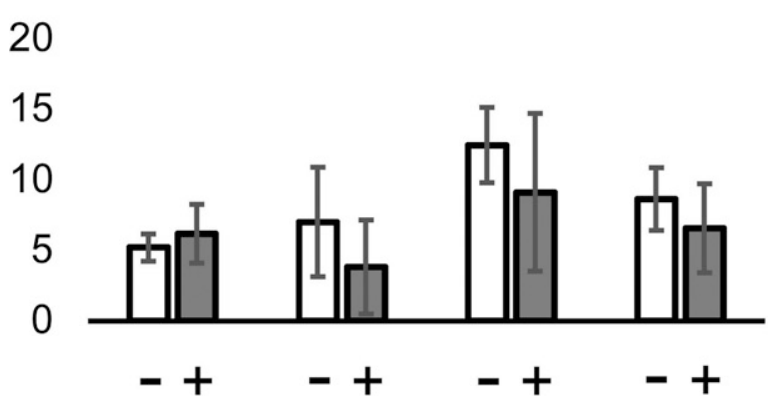

p-coumaric acid

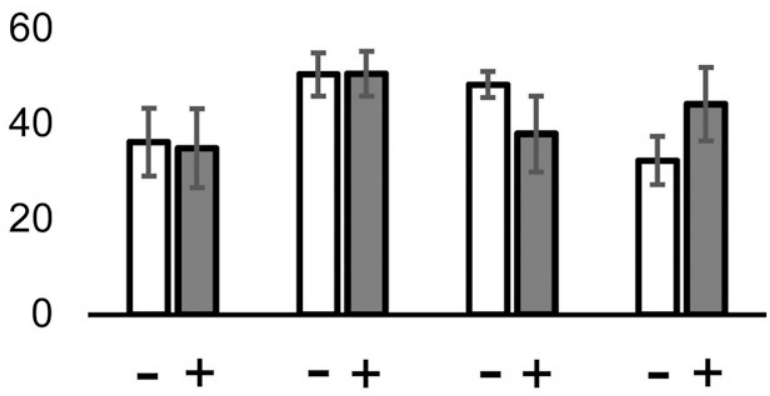

trans-ferulic acid

50

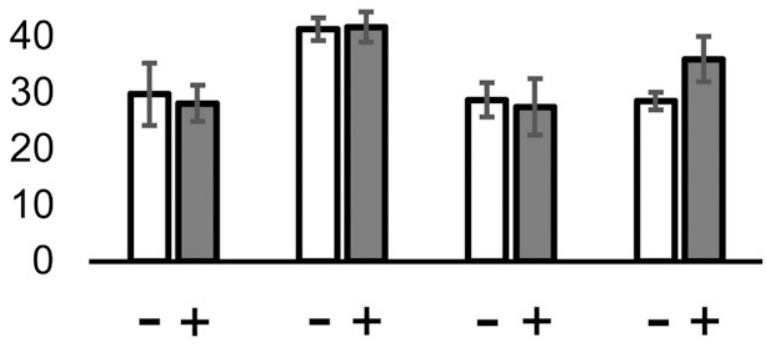

coumarin

4000

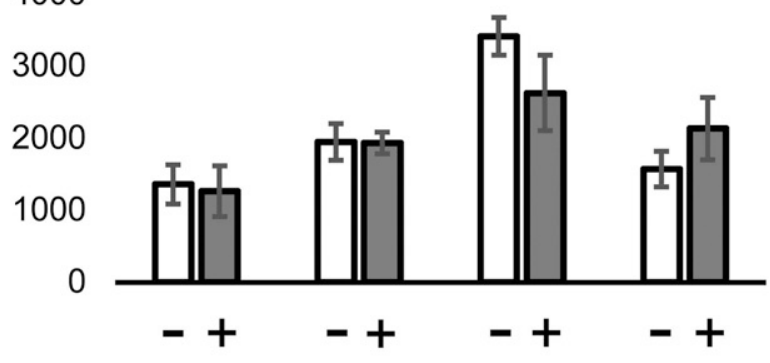

trial $1 \quad$ trial 2 trial $3 \quad$ trial 4

Fig. 4. Relative accumulation of metabolites in bean leaves treated with benzo(1,2,3)thiadiazole-7-carbothioic acid $S$-methyl ester (+) compared with nontreated controls $(-)$. Units are metabolite peak areas $\times 10^{6}$ normalized to prednisone peak areas. Peak areas were estimated with Skyline software. 
example, both R proteins and BTH-induced immune responses increase the accumulation of EDS1, SAG101, and NDR1, proteins that function in the SA-mediated defense pathway (Century et al. 1997; Cui et al. 2017; Feys et al. 2005). For the most part, these findings were expected, because it is established that BTH induces SAR and that SA is crucial for SAR (Gaffney et al. 1993; Görlach et al. 1996). Nevertheless, we were intrigued by unexpected findings like the increase of so many receptor-like kinases with possible roles in defense activation (Tables 1 and 2). Increased amounts of these proteins could explain a heightened awareness and resistance to a broad spectrum of pathogens that comes from BTH application (Lawton et al. 1996). Increased amounts of these kinases also would explain the sustained increased amounts of phosphoproteins that we observed (Table 1). Interestingly, there were two CIPP1 protein phosphatases that increased, the orthologs of which are commonly induced during SAR in A. thaliana (Blanco et al. 2009; Ding et al. 2018; Krinke et al. 2007; Wang et al. 2005). It is likely that these phosphatases work in concert with the kinases to regulate SA-mediated defense responses (Liu et al. 2018).

Not only did BTH application increase protein accumulation, it caused significant protein reductions as well. We observed reduced amounts of chloroplast proteins and reduced amounts of FLA2 that controls auxin responses and reduced amounts of the ABA-regulated water transporter PIP2;7. We previously observed reductions of FLA2 and PIP2;7 in beans with hypersensitive resistance to bean rust (Lee et al. 2009). This further substantiates the evidence that BTH alters defense pathways similarly to R-protein activation. We also previously observed reduced amounts of chloroplast proteins in beans undergoing hypersensitive resistance to rust (Lee et al. 2009). At that time, we attributed the reduction of chloroplast proteins to chlorosis, a common disease symptom arising from a loss of chlorophyll. But now, having observed that BTH reduces the accumulation of many similar chloroplast proteins, we recognize that alterations in the chloroplast proteome may be part of a coordinated defense response. Intriguingly, the chloroplast and ABA alterations may be linked, because ABA is synthesized in the chloroplast and it coordinates a chloroplast retrograde signal to affect nuclear gene expression back to the chloroplast (Zhao et al. 2019).

With respect to protection, topical application of BTH outperformed topical application of SA (Fig. 1B and C). This observation stimulates the thought that BTH application causes cellular responses that are different from SA application. A detailed comparison between the two chemicals is warranted, but the phytotoxicity of SA and the response dosages between BTH and SA would first need to be reconciled before the two chemicals could be compared side-by-side. Nevertheless, the current observations presented here are insightful. Indeed, BTH increased the accumulation of SA (Fig. 4) and increased the abundance of proteins that function through the SA-mediated defense pathway (Table 2). But we cannot yet conclude whether BTH induces novel biosynthesis of SA or whether BTH induced the release of SA from stored forms. There was no increase in PBS3 that conjugates glutamate to isochorismate for the biosynthesis of SA (Rekhter et al. 2019), but there was an increase in SABP2 that converts stored methyl-SA back to SA (Table 2) (Dempsey and Klessig 2012). Regardless of the mechanism that led to the SA accumulation, the results clearly show that BTH affected SA signaling. But BTH also affected other hormonal defense sectors. For example, decreased amounts of ACC and the concomitant increases of ACO, which converts ACC to ET, and the increased amounts of EIN2, the protein that regulates ET-signaling in the presence of ET $(\mathrm{Ju}$ et al. 2012), show that this independent hormonal pathway was induced by BTH (Table 2; Fig. 4). Meanwhile, increased amounts of IOS1 and RAE1 in BTH-treated beans imply that BTH suppressed ABA-regulated responses, while decreased amounts of FLA2 imply a suppression of auxin regulated responses (Table 2) (Hok et al. 2014; Li et al. 2018; Titapiwatanakun et al. 2009). From this, one might assume that BTH reduced $\mathrm{ABA}$ accumulation or auxin accumulation, but we did not observe reductions in ABA or auxin in whole leaf extracts (Fig. 4). It is possible that BTH alters the proteomic regulators for $\mathrm{ABA}$ and auxin without resulting in overwhelming concentrations changes like we observed for SA. Notwithstanding, the results reveal that BTH application alters proteins that function through many independent hormonal pathways, leading to an intersection of networks that provide disease resistance.

Our previous research indicates that enzymes that are part of the phenylpropanoid pathway are induced during $\mathrm{R}$ proteinmediated immunity to bean rust and that reduced amounts of soybean phenylpropanoid pathway enzymes increase susceptibility to the soybean rust fungus (Cooper et al. 2013; Lee et al. 2009). Hence, our observation that BTH increased 20 enzymes that map to the phenylpropanoid biosynthesis pathway model implied that the treated beans accumulated more phenylpropanoids. Our examination of soluble leaf extracts, however, showed no increased accumulation of pools of trans-cinnamic acid, $p$-coumaric acid, trans-ferulic acid, and coumarin. There are multiple reasons that explain this observation. First, this type of analysis does not describe flux or flow of these phenylpropanoid intermediates needed to synthesize more complex derivatives and glycosylated conjugates. In other words, there may not be increased pools of these intermediates if flow is accelerated by downstream enzyme activity. Consequently, it would be better to examine the accumulation of end-products (e.g., SA or an end-product substrate like ACC). Because BTH increases lignification in beans (Iriti and Faoro 2003), lignified end-products could be good indicators. But lignin is not easily solubilized and there are many different types of lignin, the masses of which are not easily predictable for our targeted mass spectrometry method. Another reason that may explain unaltered amounts of trans-cinnamic acid, $p$-coumaric acid, transferulic acid, and coumarin is enzyme homology. While the enzymes we detected are homologous to phenylalanine ammonia lyase that produces trans-cinnamic acid, trans-cinnamate 4-monooxygenase that produces $p$-coumaric acid, caffeic acid 3-O-methyl transferase that catalyzes trans-ferulic acid, and beta-glucosidase that produces coumarate in the phenylpropanoid biosynthesis pathway defined by the Kyoto Encyclopedia of Genes and Genomes (KEGG) database, the bean genome encodes at least five other phenylalanine ammonia lyases, two other trans-cinnamate 4-monooxygenases, 11 other caffeic acid $O$-methyl transferases, and 26 other betaglucosidases assigned to the KEGG phenylpropanoid pathway. None of these other isoforms exhibited quantitative proteomic differences. Hence, we must consider the possibility that the enzymes with increased accumulation may synthesize distinct products different from the ones we presumed and targeted. Without deeper knowledge of the array of phenylpropanoid derivatives produced in beans, we must limit ourselves to the general conclusion that the increase of at least 20 enzymes in the phenylpropanoid pathway likely contributed to disease resistance by amplifying the output of this pathway in one form or another. Other studies have reached this general conclusion by showing that some enzymes important for phenylpropanoid biosynthesis and some specific phenylpropanoid derivatives including phytoalexins are critical for rust resistance (Beyer et al. 2019; Cooper et al. 2013; Lygin et al. 2009; Maffi et al. 2011; Pandey et al. 2011). 
Overall, our results demonstrate that a 72-h exposure to BTH is sufficient to protect susceptible beans from bean rust fungal infection. BTH protects against bean rust by amplifying SAR and by altering regulators of intersecting hormonal pathways, much like R proteins do. But BTH also increases the accumulation of a variety of receptor-like kinases and other proteins involved in immunity. This protein amplification and sustained phosphorylation likely renders beans hyperaware to a broad spectrum of pathogens, including rust. We encourage others to consider SAR inducers to protect beans against rusts, especially when there is a concern that $\mathrm{R}$ proteins are no longer effective.

\section{MATERIALS AND METHODS}

Rust fungus and growth conditions.

BTH experiments were performed three separate times in early February, late February, and early March of 2019. Each time, two primary leaves from 10,7-day-old $P$. vulgaris variety Black Valentine were sprayed with a liquid suspension of Actigard (Syngenta) at $300 \mathrm{mg}$ per liter $+0.002 \%$ Tween-20 (0.7 mM BTH). A separate set of plants was sprayed with water $+0.002 \%$ Tween-20. Seventy-two hours later, six of the primary leaves were collected and frozen. The remaining 14 primary leaves on 10 plants were sprayed with a liquid suspension of uredospores of Uromyces appendiculatus race $41+0.025 \%$ $\beta$-ionone or $0.01 \%$ Tween-20, were placed in an $18^{\circ} \mathrm{C}$ dew chamber for $12 \mathrm{~h}$, and were then moved to indoor growth carts with fluorescent lighting (Lee et al. 2009). At 10 days postinoculation, rust pustules were counted in multiple $1-\mathrm{cm}^{2}$ leaf areas. This average number was multiplied by leaf area to obtain an estimate of the total number of pustules. A separate set of beans was sprayed with $4.8 \mathrm{mM}$ SA (MP Biomedicals, Solon, OH, U.S.A.) $+0.002 \%$ Tween- 20 or water + Tween-20 and were challenged as above.

\section{Peptide preparation.}

Three grams of leaves per BTH treatment per replicate were frozen in liquid nitrogen and were ground to a powder with a mortar and pestle and were further triturated in 2 volumes

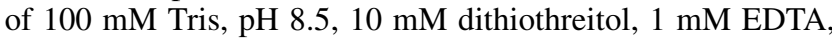
$0.5 \%$ dodecyl beta maltoside, plus manufacturer-recommended concentrations of cOmplete proteinase inhibitor (Roche, Mannheim Germany) and PhosSTOP phosphatase inhibitor (Roche). The extract was sonicated for $30 \mathrm{~s}$, and then, it was centrifuged at $1,000 \times g$ for $10 \mathrm{~min}$. Proteins were precipitated in acetone and $25 \%$ trichloroacetic acid and were isolated by centrifugation at $15,000 \times g$. The proteins were washed in acetone three times and were dried and resuspended in $8 \mathrm{M}$ urea, $100 \mathrm{mM}$ Tris, $\mathrm{pH} 8.5$, and $1 \%$ dodecyl beta maltoside. The protein concentration was determined by bicinchoninic acid assay (Pierce, Rockford, IL, U.S.A.). Proteins (approximately $600 \mu \mathrm{g})$ were reduced in Tris(2-carboxyethyl)phosphine, were carboxyamidomethylated with iodoacetamide, and were digested overnight at $37^{\circ} \mathrm{C}$ with Poroszyme immobilized trypsin (Thermo Fisher Scientific, Waltham, MA, U.S.A.). The digested peptides were purified by reverse phase chromatography, using Waters Oasis HLB 3 cc Vac Cartridges (Waters Corporation, Milford MA, U.S.A.). Peptides from each sample (360 $\mu \mathrm{g}$ each) were labeled with TMT 6-plex reagents according to manufacturer instructions (Thermo Fisher Scientific). The samples were dried and resuspended in $0.1 \%$ trifluoroacetic acid and peptides were C18-purified and their concentrations were measured with the Pierce quantitative colorimetric peptide assay (Thermo Fisher Scientific). Equivalent quantities of the tagged samples were combined to yield a $1-\mu \mathrm{g}$ aliquot that was analyzed by mass spectrometry (below) to determine label incorporation percentage (>99\%) and to estimate quantitative ratios between samples. Based on the quantitative ratios, labeled samples were mixed together. A $600-\mu \mathrm{g}$ aliquot was fractionated by high-pH reverse-phase highpressure liquid chromatography through a Waters Xbridge $3.5 \mu \mathrm{m}$ C18 column $(4.6 \times 15 \mathrm{~cm})$ with a Dionyx UltiMate 3000 pump controlling a 38 -min linear gradient from 4 to $28 \%$ acetonitrile and $0.5 \%$ triethylamine, $\mathrm{pH} 10.7$ (Wang et al. 2011). Seventy-two fractions were pooled by concatenation and were dried and resuspended in 5\% acetonitrile and $0.1 \%$ formic

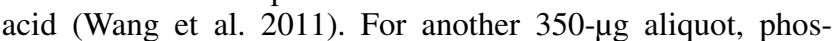
phopeptides were purified with the Pierce high-selectFe-NTA phosphopeptide enrichment kit. The phosphopeptides, the depleted flow-through, and 3 column washes were reserved, dried, and resuspended in 5\% acetonitrile and $0.1 \%$ formic acid. Peptide concentrations were measured for 12 pools plus a void volume fraction, the phosphopeptide fraction, the depleted phosphopeptide flow-through fraction, and the combined depleted column washes.

\section{Mass spectrometry.}

Peptides (approximately $1 \mu \mathrm{g}$ per fraction) were separated on a $75-\mu \mathrm{m}$ (inner diameter) fused silica capillary emitter pulled to a 5- $\mu \mathrm{m}$ tip with a P-2000 Sutter laser puller (Sutter Instrument, Novato, CA, U.S.A.), packed with $22 \mathrm{~cm}$ of a $2.5-\mu \mathrm{m}$ Synergi Hydro-RP C18 (Phenomenex, Torrance, CA, U.S.A.), and coupled directly to a Dionex UltiMate 3000 RSLC nano system (Thermo Fisher Scientific) controlling a 180-min linear gradient from 3.2 to $40 \%$ acetonitrile and $0.1 \%$ formic acid at a flow rate of $300 \mathrm{nl}$ per minute. Peptides were electrosprayed at 2.4 $\mathrm{kV}$ into an Orbitrap Fusion Lumos Tribrid mass spectrometer (Thermo Fisher Scientific) operating in data-dependent mode with positive polarity and using $445.12003 \mathrm{~m} / \mathrm{z}$ as an internal mass calibrant. Quadrupole isolation was enabled and survey scans were recorded in the Orbitrap at 120,000 resolution over a mass range of 400 to $1,600 \mathrm{~m} / \mathrm{z}$. The instrument was operated in top speed mode using the Multinotch $\mathrm{MS}^{3}$ method with a cycle time of 3 s (Isasa et al. 2015; McAlister et al. 2014). The automatic gain control (AGC) target was set to 200,000 and the maximum injection time was set to 50 milliseconds $(\mathrm{ms})$. The most abundant precursor ions (intensity threshold 5,000) were fragmented by collision-induced dissociation ( $35 \%$ energy) and fragment ions were detected in the linear ion trap (AGC 10,000, $50 \mathrm{~ms}$ maximum injection). Analyzed precursors were dynamically excluded for $45 \mathrm{~s}$. Multiple $\mathrm{MS}^{2}$ fragment ions were captured using isolation waveforms with multiple frequency notches and fragmented by high energy collision-induced dissociation (65\% normalized collision energy). $\mathrm{MS}^{3}$ spectra were acquired in the Orbitrap (AGC 100,000; maximum injection time $120 \mathrm{~ms}$, 60,000 resolution scanning from 100 to $500 \mathrm{~m} / \mathrm{z}$ ). These mass spectrometry data files can be retrieved from the MassIVE database (MSV000084162).

\section{Peptide matching and statistics.}

Mass spectrometry data were processed with Proteome Discoverer 2.1 (Thermo Fisher Scientific), which extracted $\mathrm{MS}^{2}$ spectra for peptide identification and $\mathrm{MS}^{3}$ spectra for peptide quantitation. $\mathrm{MS}^{2}$ spectra were searched with Mascot 2.6.1 against the $P$. vulgaris PI G19833 protein database $(27,433$ records in the Pvulgaris_442_v2.1protein_primaryTranscriptOnly.fa file, in the Phytozome database, appended with a list of 172 sequences to detect common contaminants). Search parameters were for tryptic digests with two possible missed cleavages, fixed amino acid modifications for chemically modified cysteine and labeled $\mathrm{N}$-terminal and internal lysine (+57.021 Da, C; +229.163 Da, K), variable oxidized methionine and phosphorylated serine, threonine, and tyrosine 
(+15.995 Da, M; +79.966 Da, S, T, and Y), monoisotopic mass values, $\pm 10 \mathrm{ppm}$ parent ion mass tolerance and \pm 0.6 Da fragment ion mass tolerance. Peptide spectrum matches (PSMs) were processed by Percolator, using delta $\mathrm{Cn}(0.05)$, strict FDR (0.01), relaxed FDR (0.05), and PEP (0.05) settings. Additional filters limited Mascot ions scores $(\geq 13)$ and PSMs and peptide PEPs (strict 0.01; relaxed 0.05). The estimated PSM strict and relaxed FDR was 0.002 . Peptides were assigned to logical protein groups using parsimony. Proteins were quantified on summed S/N ratios for each TMT channel for 61,608 qualified PSMs for unique peptides (isolation interference $<25 \%$; S/N ratio average of all channels $>2$; at least medium confidence) (Supplementary Dataset S2). The most confident centroid within $0.003 \mathrm{Da}$ of the expected mass of the reporter ions was used. TMT signals also were corrected for isotope impurities (lot-specific data provided by the manufacturer). Missing TMT signal values were replaced with a minimum value of 1 for 98 qualified PSMs. Matches to contaminants and decoys were removed from the dataset, as were proteins with quantitative signal sums across all six channels $<91$ or less than two PSMs contributing to the qualified quantitative signal sum. Protein quantitative values for each channel were normalized by the sum of quantitative values for all proteins for each channel and were scaled to 100. An empirical Bayes statistics test was used in the LIMMA package in the $\mathrm{R}$ software package to measure significant differences and to limit FDR to $\leq 0.05$ (D'Angelo et al. 2017).

Protein sequences were compared with the Swiss-Prot database (downloaded April 30, 2019) with BLASTP. Subcellular localization was predicted with DeepLoc-1.0 (Almagro Armenteros et al. 2017). KEGG identifiers were assigned to $P$. vulgaris reference sequences and were mapped to biochemical and cellular pathways (KEGG database).

\section{Metabolite analysis.}

Primary bean leaves sprayed with BTH or with water were sampled $72 \mathrm{~h}$ later for metabolite analysis. Half-leaves from two plants totaling $0.5 \mathrm{~g}$ comprised a sample. Three to four samples were analyzed per treatment and the experiments were performed four times. Leaves were ground with a pestle in a mortar with $1 \mathrm{ml}$ of ethanol. Prednisone (50 pmol) was added to the slurry. The slurry was transferred to a tube and was centrifuged for $10 \mathrm{~min}$ at $12,000 \times \mathrm{g}$. The supernatant was passed through an Oasis Prime HLB Plus Light 100-mg cartridge primed with $50 \%$ methanol and equilibrated with water. Metabolites were eluted with acetonitrile and were dried in a speed vac. Metabolites were resuspended in $1 \mathrm{ml}$ of $5 \%$ acetonitrile and $0.1 \%$ formic acid, and $1 \mu \mathrm{l}$ was injected into the Orbitrap Fusion for analysis. The settings were the same as above with the following alterations. The Dionex pump controlled a 40-min linear gradient from 3.2 to $40 \%$ acetonitrile and $0.1 \%$ formic acid at a flow rate of $300 \mathrm{nl}$ per minute. The ion transfer tube temperature was $200^{\circ} \mathrm{C}$. Quadrupole isolation was enabled and survey scans were recorded in the Orbitrap at 30,000 resolution over a mass range of 50 to $500 \mathrm{~m} / \mathrm{z}$. The AGC target was set to 400,000 . A targeted $\mathrm{MS}^{2}$ method was performed on the protonated monoisotopic precursors for SA $(139.039 \mathrm{~m} / \mathrm{z})$, ACC $(102.05 \mathrm{~m} / \mathrm{z})$, methionine $(150.06 \mathrm{~m} / \mathrm{z})$, ABA $(265.143 \mathrm{~m} / \mathrm{z}$ ), auxin (indole-3-acetic acid, $176.071 \mathrm{~m} / \mathrm{z}$ ), trans-cinnamic acid $(149.06 \mathrm{~m} / \mathrm{z}), p$-coumaric acid $(165.055$ $\mathrm{m} / \mathrm{z})$, trans-ferulic acid $(195.065 \mathrm{~m} / \mathrm{z})$, coumarin $(147.044 \mathrm{~m} / \mathrm{z})$, and prednisone $(359.19 \mathrm{~m} / \mathrm{z})$. Precursors selected within a 1.6$\mathrm{Da}$ isolation window were fragmented by high-energy collision-induced dissociation $(30 \%$ normalized collision energy), and fragment ions were resolved in the Orbitrap at 30,000 resolution. Raw result files were analyzed with Skyline version 4.2.0.19009. Peak areas were generated from $\mathrm{MS}^{2}$ protonated ion transitions for SA (139.0390, 121.0290, 93.0340 at approximately $18 \mathrm{~min}), \mathrm{ACC}$ (56.0500 at approximately $5 \mathrm{~min})$, methionine $(104.0530,102.0560,56.0500$ at approximately $6 \mathrm{~min})$, ABA (201.1270, 187.1110, 173.1330, 163.0760, $135.0810,121.0650$ at approximately $17 \mathrm{~min})$, auxin $(130.0650$, $117.0570,103.0540,77.0390$ at approximately $30 \mathrm{~min})$, transcinnamic acid $(131.0500,103.0550,77.0391$ at approximately $12 \mathrm{~min}), p$-coumaric acid $(147.0450,119.0450,91.0540$ approximately $26 \mathrm{~min})$, trans-ferulic acid (177.0550, 149.0600, $145.0285,117.0340$ at approximately $27 \mathrm{~min}$ ), coumarin (147.0446, $119.0490,91.0550,77.0391$ at approximately $26 \mathrm{~min})$, and prednisone $(147.0810,135.0810,121.0650,95.0870$ at approximately $35 \mathrm{~min}$ ). Because in-source fragmentation of methionine generates a $56.0500 \mathrm{~m} / \mathrm{z}$ ion that is an isomer of the ACC transition, peak area selections for ACC were terminated when the first transitions for methionine were detected. Metabolite peak areas were normalized to prednisone peak areas per sample. The transitions originally were selected by analyzing $\mathrm{MS}^{2}$ spectra from $500 \mathrm{pmol}$ of each purified metabolite (purchased from Sigma-Aldrich, St. Louis). Transition masses are supported by predicted molecular derivative structures at PubChem.

\section{AUTHOR-RECOMMENDED INTERNET RESOURCES}

KEGG database: https://www.kegg.jp

MassIVE database: https://massive.ucsd.edu/ProteoSAFe/static/massive.jsp Phytozome database: https://phytozome.jgi.doe.gov

PubChem: pubchem.ncbi.nlm.nih.gov

\section{LITERATURE CITED}

Albert, I., Böhm, H., Albert, M., Feiler, C. E., Imkampe, J., Wallmeroth, N., Brancato, C., Raaymakers, T. M., Oome, S., Zhang, H., Krol, E., Grefen, C., Gust, A. A., Chai, J., Hedrich, R., Van den Ackerveken, G., and Nürnberger, T. 2015. An RLP23-SOBIR1-BAK1 complex mediates NLP-triggered immunity. Nat. Plants 1:15140.

Almagro Armenteros, J. J., Sønderby, C. K., Sønderby, S. K., Nielsen, H., and Winther, O. 2017. DeepLoc: prediction of protein subcellular localization using deep learning. Bioinformatics 33:4049-4049.

Azevedo, C., Sadanandom, A., Kitagawa, K., Freialdenhoven, A., Shirasu, K., and Schulze-Lefert, P. 2002. The RAR1 interactor SGT1, an essential component of R gene-triggered disease resistance. Science 295:2073-2076.

Bernsdorff, F., Döring, A. C., Gruner, K., Schuck, S., Bräutigam, A., and Zeier, J. 2016. Pipecolic acid orchestrates plant systemic acquired resistance and defense priming via salicylic acid-dependent and -independent pathways. Plant Cell 28:102-129.

Beyer, S. F., Beesley, A., Rohmann, P. F. W., Schultheiss, H., Conrath, U., and Langenbach, C. J. G. 2019. The Arabidopsis non-host defenceassociated coumarin scopoletin protects soybean from Asian soybean rust. Plant J. 99:397-413.

Blanco, F., Salinas, P., Cecchini, N. M., Jordana, X., Van Hummelen, P., Alvarez, M. E., and Holuigue, L. 2009. Early genomic responses to salicylic acid in Arabidopsis. Plant Mol. Biol. 70:79-102.

Bolwell, G. P., Robbins, M. P., and Dixon, R. A. 1985. Metabolic changes in elicitor-treated bean cells. Enzymic responses associated with rapid changes in cell wall components. Eur. J. Biochem. 148:571-578.

Boursiac, Y., Chen, S., Luu, D. T., Sorieul, M., van den Dries, N., and Maurel, C. 2005. Early effects of salinity on water transport in Arabidopsis roots. Molecular and cellular features of aquaporin expression. Plant Physiol. 139:790-805.

Century, K. S., Shapiro, A. D., Repetti, P. P., Dahlbeck, D., Holub, E., and Staskawicz, B. J. 1997. NDR1, a pathogen-induced component required for Arabidopsis disease resistance. Science 278:1963-1965.

Chen, Y. C., Holmes, E. C., Rajniak, J., Kim, J. G., Tang, S., Fischer, C. R., Mudgett, M. B., and Sattely, E. S. 2018. $N$-hydroxy-pipecolic acid is a mobile metabolite that induces systemic disease resistance in Arabidopsis. Proc. Natl. Acad. Sci. U.S.A. 115:E4920-E4929.

Clay, N. K., Adio, A. M., Denoux, C., Jander, G., and Ausubel, F. M. 2009. Glucosinolate metabolites required for an Arabidopsis innate immune response. Science 323:95-101.

Cook, D. E., Mesarich, C. H., and Thomma, B. P. 2015. Understanding plant immunity as a surveillance system to detect invasion. Annu. Rev. Phytopathol. 53:541-563. 
Cooper, B., Campbell, K. B., McMahon, M. B., and Luster, D. G. 2013. Disruption of Rppl-mediated soybean rust immunity by virus-induced gene silencing. Plant Signal. Behav. 8:e27543.

Cui, H., Gobbato, E., Kracher, B., Qiu, J., Bautor, J., and Parker, J. E. 2017. A core function of EDS1 with PAD4 is to protect the salicylic acid defense sector in Arabidopsis immunity. New Phytol. 213:1802-1817.

D’Angelo, G., Chaerkady, R., Yu, W., Hizal, D. B., Hess, S., Zhao, W., Lekstrom, K., Guo, X., White, W. I., Roskos, L., Bowen, M. A., and Yang, H. 2017. Statistical models for the analysis of isobaric tags multiplexed quantitative proteomics. J. Proteome Res. 16:3124-3136.

Delaney, T. P., Uknes, S., Vernooij, B., Friedrich, L., Weymann, K. Negrotto, D., Gaffney, T., Gut-Rella, M., Kessmann, H., Ward, E., and Ryals, J. 1994. A central role of salicylic acid in plant disease resistance. Science 266:1247-1250.

Dempsey, D. A., and Klessig, D. F. 2012. SOS-Too many signals for systemic acquired resistance? Trends Plant Sci. 17:538-545.

Ding, Y., Sun, T., Ao, K., Peng, Y., Zhang, Y., and Li, X. 2018. Opposite roles of salicylic acid receptors NPR1 and NPR3/NPR4 in transcriptional regulation of plant immunity. Cell 173:1454-1467.

Dong, C. J., Cao, N., Li, L., and Shang, Q. M. 2016. Quantitative proteomic profiling of early and late responses to salicylic acid in cucumber leaves. PLoS One 11:e0161395.

Erwig, J., Ghareeb, H., Kopischke, M., Hacke, R., Matei, A., Petutschnig, E., and Lipka, V. 2017. Chitin-induced and CHITIN ELICITOR RECEPTOR KINASE1 (CERK1) phosphorylation-dependent endocytosis of Arabidopsis thaliana LYSIN MOTIF-CONTAINING RECEPTOR-LIKE KINASE5 (LYK5). New Phytol. 215:382-396.

Feys, B. J., Wiermer, M., Bhat, R. A., Moisan, L. J., Medina-Escobar, N., Neu, C., Cabral, A., and Parker, J. E. 2005. Arabidopsis SENESCENCEASSOCIATED GENE101 stabilizes and signals within an ENHANCED DISEASE SUSCEPTIBILITY1 complex in plant innate immunity. Plant Cell 17:2601-2613

Gaffney, T., Friedrich, L., Vernooij, B., Negrotto, D., Nye, G., Uknes, S., Ward, E., Kessmann, H., and Ryals, J. 1993. Requirement of salicylic acid for the induction of systemic acquired resistance. Science 261: 754-756.

Glazebrook, J., Chen, W., Estes, B., Chang, H. S., Nawrath, C., Métraux, J. P., Zhu, T., and Katagiri, F. 2003. Topology of the network integrating salicylate and jasmonate signal transduction derived from global expression phenotyping. Plant J. 34:217-228.

Görlach, J., Volrath, S., Knauf-Beiter, G., Hengy, G., Beckhove, U., Kogel, K. H., Oostendorp, M., Staub, T., Ward, E., Kessmann, H., and Ryals, J. 1996. Benzothiadiazole, a novel class of inducers of systemic acquired resistance, activates gene expression and disease resistance in wheat. Plant Cell 8:629-643.

Guo, H., Nolan, T. M., Song, G., Liu, S., Xie, Z., Chen, J., Schnable, P. S., Walley, J. W., and Yin, Y. 2018. FERONIA receptor kinase contributes to plant immunity by suppressing jasmonic acid signaling in Arabidopsis thaliana. Curr. Biol. 28:3316-3324.

Hartmann, M., Zeier, T., Bernsdorff, F., Reichel-Deland, V., Kim, D., Hohmann, M., Scholten, N., Schuck, S., Brautigam, A., Holzel, T., Ganter, C., and Zeier, J. 2018. Flavin monooxygenase-generated $\mathrm{N}$ hydroxypipecolic acid is a critical element of plant systemic immunity. Cell 173:456-469.

Hok, S., Allasia, V., Andrio, E., Naessens, E., Ribes, E., Panabières, F., Attard, A., Ris, N., Clément, M., Barlet, X., Marco, Y., Grill, E., Eichmann, R., Weis, C., Hückelhoven, R., Ammon, A., Ludwig-Müller, J., Voll, L. M., and Keller, H. 2014. The receptor kinase IMPAIRED OOMYCETE SUSCEPTIBILITY1 attenuates abscisic acid responses in Arabidopsis. Plant Physiol. 166:1506-1518.

Hurtado-Gonzales, O. P., Valentini, G., Gilio, T. A., Martins, A. M., Song, Q., and Pastor-Corrales, M. A. 2017. Fine mapping of $U r-3$, a historically important rust resistance locus in common bean. G3 (Bethesda) 7:557-569.

Iriti, M., and Faoro, F. 2003. Benzothiadiazole (BTH) induces cell-death independent resistance in Phaseolus vulgaris against Uromyces appendiculatus. J. Phytopathol. 151:171-180.

Isasa, M., Rose, C. M., Elsasser, S., Navarrete-Perea, J., Paulo, J. A., Finley, D. J., and Gygi, S. P. 2015. Multiplexed, Proteome-Wide Protein Expression Profiling: Yeast Deubiquitylating Enzyme Knockout Strains. J. Proteome Res. 14:5306-5317.

Jang, J. Y., Kim, D. G., Kim, Y. O., Kim, J. S., and Kang, H. 2004. An expression analysis of a gene family encoding plasma membrane aquaporins in response to abiotic stresses in Arabidopsis thaliana. Plant Mol. Biol. 54:713-725

Ju, C., Yoon, G. M., Shemansky, J. M., Lin, D. Y., Ying, Z. I., Chang, J., Garrett, W. M., Kessenbrock, M., Groth, G., Tucker, M. L., Cooper, B., Kieber, J. J., and Chang, C. 2012. CTR1 phosphorylates the central regulator EIN2 to control ethylene hormone signaling from the ER membrane to the nucleus in Arabidopsis. Proc. Natl. Acad. Sci. U.S.A. 109:19486-19491.

Kim, K. N., Cheong, Y. H., Grant, J. J., Pandey, G. K., and Luan, S. 2003. CIPK3, a calcium sensor-associated protein kinase that regulates abscisic acid and cold signal transduction in Arabidopsis. Plant Cell 15:411-423.

Klessig, D. F., Choi, H. W., and Dempsey, D. A. 2018. Systemic acquired resistance and salicylic acid: Past, present, and future. Mol. PlantMicrobe Interact. 31:871-888.

Kliebenstein, D. J., West, M. A., van Leeuwen, H., Kim, K., Doerge, R. W., Michelmore, R. W., and St. Clair, D. A. 2006. Genomic survey of gene expression diversity in Arabidopsis thaliana. Genetics 172:1179-1189.

Kohler, A., Schwindling, S., and Conrath, U. 2002. Benzothiadiazoleinduced priming for potentiated responses to pathogen infection, wounding, and infiltration of water into leaves requires the NPRI/NIMI gene in Arabidopsis. Plant Physiol. 128:1046-1056.

Krinke, O., Ruelland, E., Valentová, O., Vergnolle, C., Renou, J. P. Taconnat, L., Flemr, M., Burketová, L., and Zachowski, A. 2007. Phosphatidylinositol 4-kinase activation is an early response to salicylic acid in Arabidopsis suspension cells. Plant Physiol. 144:1347-1359.

Kumar, D., and Klessig, D. F. 2003. High-affinity salicylic acid-binding protein 2 is required for plant innate immunity and has salicylic acidstimulated lipase activity. Proc. Natl. Acad. Sci. U.S.A. 100: 16101-16106.

Lawton, K. A., Friedrich, L., Hunt, M., Weymann, K., Delaney, T., Kessmann, H., Staub, T., and Ryals, J. 1996. Benzothiadiazole induces disease resistance in Arabidopsis by activation of the systemic acquired resistance signal transduction pathway. Plant J. 10:71-82

Lee, J., Feng, J., Campbell, K. B., Scheffler, B. E., Garrett, W. M., Thibivilliers, S., Stacey, G., Naiman, D. Q., Tucker, M. L., PastorCorrales, M. A., and Cooper, B. 2009. Quantitative proteomic analysis of bean plants infected by a virulent and avirulent obligate rust fungus. Mol. Cell. Proteomics 8:19-31.

Li, D., Zhang, L., Li, X., Kong, X., Wang, X., Li, Y., Liu, Z., Wang, J., Li, X., and Yang, Y. 2018. AtRAE1 is involved in degradation of ABA receptor RCAR1 and negatively regulates ABA signalling in Arabidopsis. Plant Cell Environ. 41:231-244.

Liu, J., Liu, B., Chen, S., Gong, B. Q., Chen, L., Zhou, Q., Xiong, F., Wang, M., Feng, D., Li, J. F., Wang, H. B., and Wang, J. 2018. A tyrosine phosphorylation cycle regulates fungal activation of a plant receptor Ser/Thr kinase. Cell Host Microbe 23:241-253.

Lygin, A. V., Li, S., Vittal, R., Widholm, J. M., Hartman, G. L., and Lozovaya, V. V. 2009. The importance of phenolic metabolism to limit the growth of Phakopsora pachyrhizi. Phytopathology 99:1412-1420.

Maffi, D., Iriti, M., Pigni, M., Vannini, C., and Faoro, F. 2011. Uromyces appendiculatus infection in BTH-treated bean plants: Ultrastructura details of a lost fight. Mycopathologia 171:209-221.

McAlister, G. C., Nusinow, D. P., Jedrychowski, M. P., Wühr, M., Huttlin, E. L., Erickson, B. K., Rad, R., Haas, W., and Gygi, S. P. 2014 MultiNotch MS3 enables accurate, sensitive, and multiplexed detection of differential expression across cancer cell line proteomes. Anal. Chem. 86:7150-7158

Miya, A., Albert, P., Shinya, T., Desaki, Y., Ichimura, K., Shirasu, K., Narusaka, Y., Kawakami, N., Kaku, H., and Shibuya, N. 2007. CERK1, a LysM receptor kinase, is essential for chitin elicitor signaling in Arabidopsis. Proc. Natl. Acad. Sci. U.S.A. 104:19613-19618.

Nawrath, C., and Métraux, J. P. 1999. Salicylic acid induction-deficient mutants of Arabidopsis express $P R-2$ and $P R-5$ and accumulate high levels of camalexin after pathogen inoculation. Plant Cell 11: 1393-1404.

Noh, B., Murphy, A. S., and Spalding, E. P. 2001. Multidrug resistance-like genes of Arabidopsis required for auxin transport and auxin-mediated development. Plant Cell 13:2441-2454.

Oh, E., Zhu, J. Y., Ryu, H., Hwang, I., and Wang, Z. Y. 2014. TOPLESS mediates brassinosteroid-induced transcriptional repression through interaction with BZR1. Nat. Commun. 5:4140.

Pandey, A. K., Yang, C., Zhang, C., Graham, M. A., Horstman, H. D., Lee, Y., Zabotina, O. A., Hill, J. H., Pedley, K. F., and Whitham, S. A. 2011 Functional analysis of the Asian soybean rust resistance pathway mediated by Rpp2. Mol. Plant-Microbe Interact. 24:194-206.

Pou, A., Jeanguenin, L., Milhiet, T., Batoko, H., Chaumont, F., and Hachez, C. 2016. Salinity-mediated transcriptional and post-translational regulation of the Arabidopsis aquaporin PIP2;7. Plant Mol. Biol. 92: 731-744.

Rekhter, D., Lüdke, D., Ding, Y., Feussner, K., Zienkiewicz, K., Lipka, V., Wiermer, M., Zhang, Y., and Feussner, I. 2019. Isochorismate-derived biosynthesis of the plant stress hormone salicylic acid. Science 365: 498-502. 
Robbins, M. P., Bolwell, G. P., and Dixon, R. A. 1985. Metabolic changes in elicitor-treated bean cells. Selectivity of enzyme induction in relation to phytoalexin accumulation. Eur. J. Biochem. 148:563-569.

Shah, J., Chaturvedi, R., Chowdhury, Z., Venables, B., and Petros, R. A. 2014. Signaling by small metabolites in systemic acquired resistance. Plant J. 79:645-658.

Shapiro, A. D., and Zhang, C. 2001. The role of NDRl in avirulence genedirected signaling and control of programmed cell death in Arabidopsis. Plant Physiol. 127:1089-1101.

Sillero, J. C., Rojas-Molina, M. M., Avila, C. M., and Rubiales, D. 2012. Induction of systemic acquired resistance against rust, ascochyta blight and broomrape in faba bean by exogenous application of salicylic acid and benzothiadiazole. Crop Prot. 34:65-69.

Tateda, C., Zhang, Z., Shrestha, J., Jelenska, J., Chinchilla, D., and Greenberg, J. T. 2014. Salicylic acid regulates Arabidopsis microbial pattern receptor kinase levels and signaling. Plant Cell 26:4171-4187.

Tejos, R., Rodriguez-Furlán, C., Adamowski, M., Sauer, M., Norambuena, L., and Friml, J. 2018. PATELLINS are regulators of auxin-mediated PIN1 relocation and plant development in Arabidopsis thaliana. J. Cell Sci. 131:204198.

Tintor, N., Ross, A., Kanehara, K., Yamada, K., Fan, L., Kemmerling, B., Nürnberger, T., Tsuda, K., and Saijo, Y. 2013. Layered pattern receptor signaling via ethylene and endogenous elicitor peptides during Arabidopsis immunity to bacterial infection. Proc. Natl. Acad. Sci. U.S.A. 110:6211-6216.

Titapiwatanakun, B., Blakeslee, J. J., Bandyopadhyay, A., Yang, H., Mravec, J., Sauer, M., Cheng, Y., Adamec, J., Nagashima, A., Geisler, M., Sakai, T., Friml, J., Peer, W. A., and Murphy, A. S. 2009. ABCB19/PGP19 stabilises PIN1 in membrane microdomains in Arabidopsis. Plant J. 57:27-44.

Tsuda, K., Sato, M., Stoddard, T., Glazebrook, J., and Katagiri, F. 2009. Network properties of robust immunity in plants. PLoS Genet. 5:e1000772.

van Loon, L. C., Rep, M., and Pieterse, C. M. J. 2006. Significance of inducible defense-related proteins in infected plants. Annu. Rev. Phytopathol. 44:135-162.

Vogel, C., and Marcotte, E. M. 2012. Insights into the regulation of protein abundance from proteomic and transcriptomic analyses. Nat. Rev. Genet. $13: 227-232$.

Wang, D., Weaver, N. D., Kesarwani, M., and Dong, X. 2005. Induction of protein secretory pathway is required for systemic acquired resistance. Science 308:1036-1040.

Wang, Y., Yang, F., Gritsenko, M. A., Wang, Y., Clauss, T., Liu, T., Shen, Y., Monroe, M. E., Lopez-Ferrer, D., Reno, T., Moore, R. J., Klemke, R. L., Camp, D. G., 2nd, and Smith, R. D. 2011. Reversed-phase chromatography with multiple fraction concatenation strategy for proteome profiling of human MCF10A cells. Proteomics 11:2019-2026.

Wu, L., Hu, X., Wang, S., Tian, L., Pang, Y., Han, Z., Wu, L., and Chen, Y. 2015. Quantitative analysis of changes in the phosphoproteome of maize induced by the plant hormone salicylic acid. Sci. Rep. 5:18155.

Yeh, Y. H., Panzeri, D., Kadota, Y., Huang, Y. C., Huang, P. Y., Tao, C. N., Roux, M., Chien, H. C., Chin, T. C., Chu, P. W., Zipfel, C., and Zimmerli, L. 2016. The Arabidopsis malectin-like/LRR-RLK IOS1 is critical for BAK1-dependent and BAK1-independent pattern-triggered immunity. Plant Cell 28:1701-1721.

Yuan, T., Fujioka, S., Takatsuto, S., Matsumoto, S., Gou, X., He, K., Russell, S. D., and Li, J. 2007. BEN1, a gene encoding a dihydroflavonol 4-reductase (DFR)-like protein, regulates the levels of brassinosteroids in Arabidopsis thaliana. Plant J. 51:220-233.

Zhang, B., Van Aken, O., Thatcher, L., De Clercq, I., Duncan, O., Law, S. R., Murcha, M. W., van der Merwe, M., Seifi, H. S., Carrie, C., Cazzonelli, C., Radomiljac, J., Höfte, M., Singh, K. B., Van Breusegem, F., and Whelan, J. 2014a. The mitochondrial outer membrane AAA ATPase AtOM66 affects cell death and pathogen resistance in Arabidopsis thaliana. Plant J. 80:709-727.

Zhang, W., Fraiture, M., Kolb, D., Löffelhardt, B., Desaki, Y., Boutrot, F. F., Tör, M., Zipfel, C., Gust, A. A., and Brunner, F. 2013. Arabidopsis receptor-like protein30 and receptor-like kinase suppressor of BIR11/EVERSHED mediate innate immunity to necrotrophic fungi. Plant Cell 25:4227-4241.

Zhang, X. N., Mo, C., Garrett, W. M., and Cooper, B. 2014b. Phosphothreonine 218 is required for the function of SR45.1 in regulating flower petal development in Arabidopsis. Plant Signal. Behav. 9:e29134.

Zhang, X. N., Shi, Y., Powers, J. J., Gowda, N. B., Zhang, C., Ibrahim, H. M. M., Ball, H. B., Chen, S. L., Lu, H., and Mount, S. M. 2017a. Transcriptome analyses reveal SR45 to be a neutral splicing regulator and a suppressor of innate immunity in Arabidopsis thaliana. BMC Genomics 18:772.

Zhang, Y., Zhao, L., Zhao, J., Li, Y., Wang, J., Guo, R., Gan, S., Liu, C. J., and Zhang, K. 2017b. S5H/DMR6 encodes a salicylic acid 5-hydroxylase that fine-tunes salicylic acid homeostasis. Plant Physiol. 175:1082-1093.

Zhao, C., Wang, Y., Chan, K. X., Marchant, D. B., Franks, P. J., Randall, D., Tee, E. E., Chen, G., Ramesh, S., Phua, S. Y., Zhang, B., Hills, A., Dai, F., Xue, D., Gilliham, M., Tyerman, S., Nevo, E., Wu, F., Zhang, G., Wong, G. K., Leebens-Mack, J. H., Melkonian, M., Blatt, M. R., Soltis, P. S., Soltis, D. E., Pogson, B. J., and Chen, Z. H. 2019. Evolution of chloroplast retrograde signaling facilitates green plant adaptation to land. Proc. Natl. Acad. Sci. U.S.A. 116:5015-5020. 